Article

\title{
New Diterpenes from Arenga pinnata (Wurmb.) Merr. Fruits
}

\author{
Ji-Fei Liu ${ }^{1}$, Jin-Hai Huo ${ }^{1}$, Chang Wang ${ }^{1}$, Feng-Jin Li ${ }^{1}$, Wei-Ming Wang ${ }^{1, *}$ and Lu-Qi Huang ${ }^{2, *}$ \\ 1 Institute of Chinese Materia Medica, Heilongjiang Academy of Chinese Medicine Sciences, \\ Harbin 150036, China; liujifei2019@163.com (J.-F.L.); jinhaihuo@126.com (J.-H.H.); \\ wangchang89993762@126.com (C.W.); wklifengjin@163.com (F.-J.L.) \\ 2 National Resource Center for Chinese Materia Medica, China Academy of Chinese Medical Sciences, \\ Beijing 100700, China \\ * Correspondence: zyyjy@163.com (W.-M.W.); huangluqi01@126.com (L.-Q.H.); \\ Tel.: +86-0451-5566-5478 (W.-M.W.); +86-10-6401-4411 (L.-Q.H.)
}

Received: 29 November 2018; Accepted: 26 December 2018; Published: 27 December 2018

\begin{abstract}
Three new ent-kauran-type diterpenes (1-3), named arenterpenoids A-C, and five known ones (4-8) were isolated and identified from Arenga pinnata (Wurmb.) Merr. Fruits. The structures of these compounds were established by 1D and 2D NMR spectra and HR-ESI-MS. To the best of our knowledge, this is the first scientific report of diterpenes from Arenga genus.
\end{abstract}

Keywords: Arenga pinnata (Wurmb.) Merr.; ent-kauran-type diterpene; arenterpenoids

\section{Introduction}

Arenga pinnata (Wurmb.) Merr. are tall evergreen trees belonging to the genus Arenga of the family Palmae. They are widely distributed in Southeast Asian countries, including China. A. pinnata fruits are the fruits of the A. pinnata. [1]. As a kind of folk medicine, it was first recorded in the Song Dynasty's "Kai Bao Ben Cao" and the Ming Dynasty's "Ben Cao Hui Yan" [2,3]. In the folk literature, A. pinnata fruits are made into medicinal liquor, which is rapid and significant in relieving pain [4]. A. pinnata fruits have significant effects on local neuropathic pain, rheumatism, bone pain and traumatic pain [5]. It is abundant and there is a huge development space [6]. At present, the secondary metabolites from A. pinnata fruits have not been reported, and its main effective medicinal ingredients are still not clear. Palm plants contain terpenes, alcohols, alkanes, esters, phenols, quinones, aldehydes and alkaloids, etc [7-9]. In recent years, studies have shown that diterpenes have excellent anti-tumor effects in vivo and in vitro $[10,11]$. The total diterpene of Rabdosia excisa has significant inhibitory effects on P-388, H-22, and Lewis B-16 tumor cells [12]; the diterpenes of Pteris semipinnata L. have significant inhibitory effects on A 549 and CNE-2 tumor cells [13]. This study is the first separation of the Arenga genus by silica gel and ODS column chromatography. We analyzed the chemical constituents of $A$. pinnata fruits and identified three new diterpenes named arenterpenoids A (1), B (2), and C (3) together with known pseudaminic acids (4) [14], $12 \alpha$-( $\beta$-D-glucopyranosyl)-7 $\beta$-hydroxy-kaurenolide (5) [15], paniculoside (6) [16], agittarioside b (7) [17], and orychoside B (8) [18]. This report covers the separation and structural analysis of these compounds 1-8 Figure 1. 


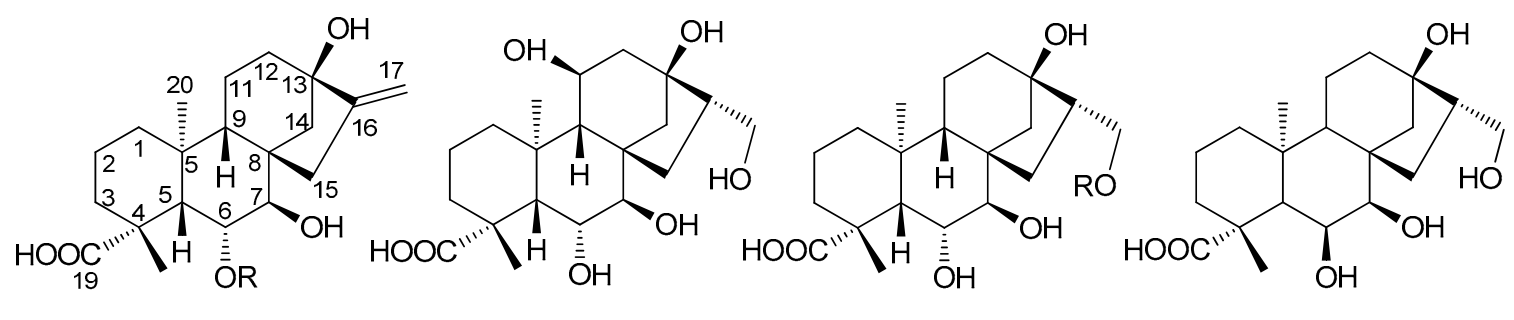

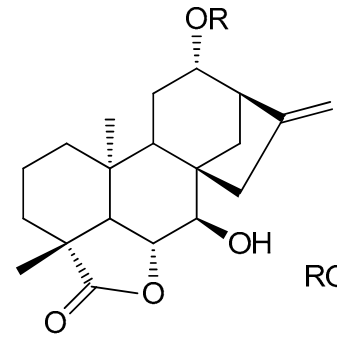

5

$\mathrm{R}=\beta$-D-glucopyranoside

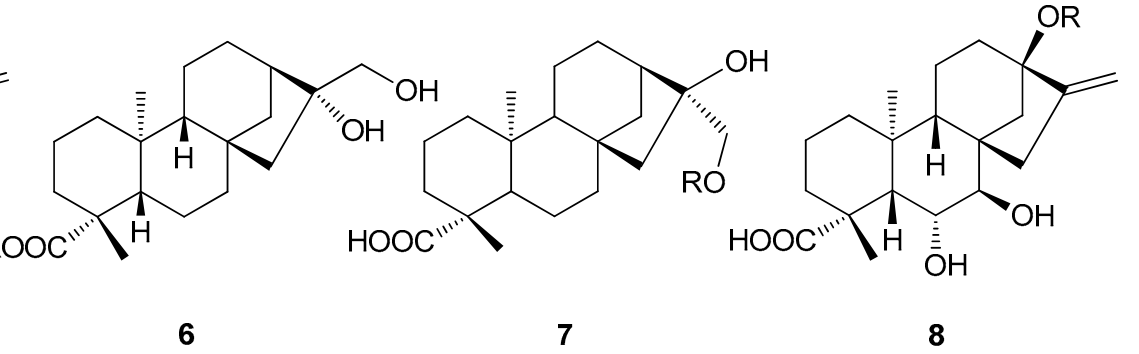

Figure 1. Structures of compounds 1-8 from of Arenga pinnata (Wurmb.) Merr. ruits.

\section{Results}

Compound 1 possessed the molecular formula of $\mathrm{C}_{26} \mathrm{H}_{40} \mathrm{O}_{10}$ according to the HR-ESI-MS at $m / z 513.2651[\mathrm{M}+\mathrm{H}]^{+}$. The acid hydrolysis of $\mathbf{1}$ liberated D-glucose, which was identified by HPLC analysis using an optical rotation detector. ${ }^{1} \mathrm{H}-\mathrm{NMR}$ spectrum (Table 1) of $\mathbf{1}$ showed two methyl signals at $\delta_{\mathrm{H}} 1.28(3 \mathrm{H}, \mathrm{s}), \delta_{\mathrm{H}} 0.86(3 \mathrm{H}, \mathrm{s})$; two olefinic proton signals at $\delta_{\mathrm{H}} 5.0(1 \mathrm{H}, \mathrm{br} . \mathrm{s}), \delta_{\mathrm{H}} 5.39(1 \mathrm{H}$, br. s); an anomeric proton signal at $\delta_{\mathrm{H}} 4.40(1 \mathrm{H}, \mathrm{d}, J=7.8 \mathrm{~Hz})$. The ${ }^{13} \mathrm{C}-\mathrm{NMR}$ and DEPT spectrum (Table 1) of 1 showed an ent-kauran-type diterpene skeleton [19]. The compound structure has 26 carbon signals, five methylene signals at $\delta c 18.4,19.8,29.2,38.4,39.2$; as well as four quaternary carbon signals at $\delta \mathrm{c} 35.2,43.0,44.6,85.4$; a carbonyl carbon signal at $\delta \mathrm{c} 184.8$; and two olefinic carbon signals at $\delta_{C} 109.7$ and 158.0. The sugar moiety consisted of six carbon signals at $\delta c 100.1,75.2,78.1,71.7,78.0$, and 62.9 [20]. The ${ }^{1} \mathrm{H}-{ }^{1} \mathrm{H}$ COSY and HSQC analysis of $\mathbf{1}$ showed the structures A, B and C (Figure 2). The connectivity of these partial structures and their functional groups were investigated by analysis of HMBC. As shown in Figure 2, the long range correlations were observed between the following protons and carbon signals: $\mathrm{H}-18\left(\mathrm{CH}_{3}\right)$ and $\mathrm{C}-3, \mathrm{C}-4, \mathrm{C}-5, \mathrm{C}-19(\mathrm{COOH}) ; \mathrm{H}-20\left(\mathrm{CH}_{3}\right)$ and $\mathrm{C}-1, \mathrm{C}-5$, C-9, C-10; H-15 and C-7, C-8, C-9, C-16; H-14 and C-12, C-13, C-16; H-17 and C-16. Thus, structure 1 was confirmed as shown in Figure 2.

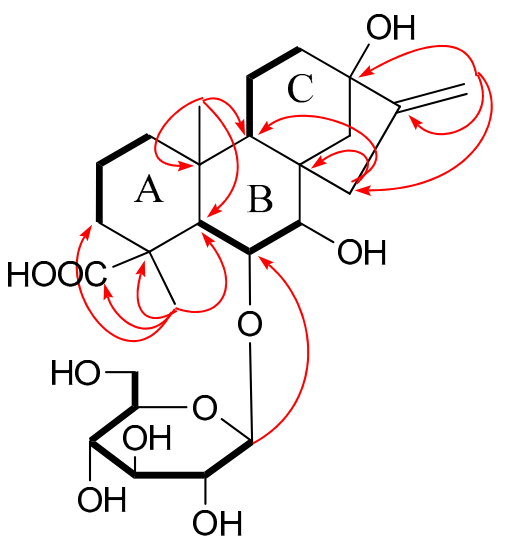

1

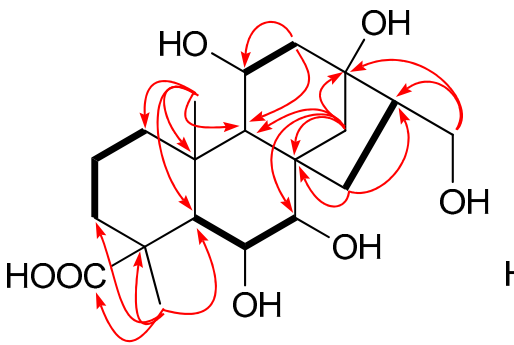

$\begin{array}{ll}\longrightarrow & { }^{1} \mathrm{H}-{ }^{1} \mathrm{HCOSY} \\ & \mathrm{HMBC}\end{array}$

2

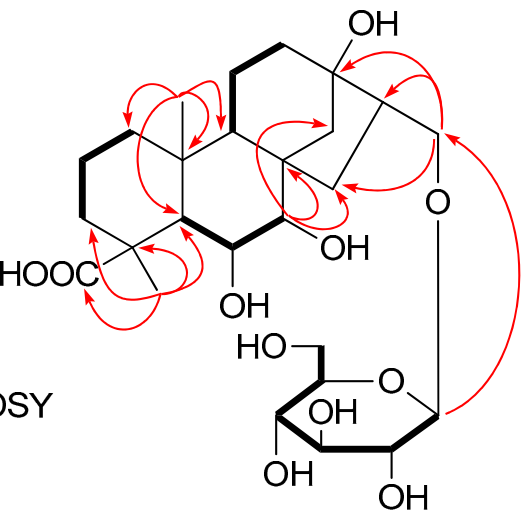

3

Figure 2. Key $\mathrm{HMBC}$ and ${ }^{1} \mathrm{H}^{1}{ }^{1} \mathrm{H}$ COSY correlations of compound 1-3. 
The coupling constants of H-6 (dd, $J_{5,6}=6.5 \mathrm{~Hz}$ and $\left.J_{6,7}=6.5 \mathrm{~Hz}\right)$ and H-7 $\left(\mathrm{d}, J_{6,7}=6.5 \mathrm{~Hz}\right)$ observed in the ${ }^{1} \mathrm{H}-\mathrm{NMR}$ spectrum were the same as those of $\mathrm{H}-6$ (dd, $J_{5,6}=6.5 \mathrm{~Hz}$ and $\left.J_{6,7}=6.5 \mathrm{~Hz}\right)$ and $\mathrm{H}-7\left(\mathrm{~d}, J_{6,7}=6.5 \mathrm{~Hz}\right)$ in $7 \beta, 16 \alpha, 17$-trihydroxy-ent-kauran-6 $\alpha, 19$-olide [21]. Thus, it was determined that $\mathrm{H}-6$ was in the $\beta$-orientation and that $\mathrm{H}-7$ was in the $\alpha$-orientation. The relative stereochemistry of 1 was assigned by analysis of the NOESY spectrum. The NOESY correlations (Figure 3) of H-6/H-18, H-7/H-20 suggested that the configurations of C-18, C-20 were restricted as $18 \beta, 20 \alpha$, respectively. Likewise, the NOESY cross-peaks of $\mathrm{H}-19 / \mathrm{H}-5, \mathrm{H}-5 / \mathrm{H}-9$ and $\mathrm{H}-9 / \mathrm{H}-15$ showed that the configurations of $\mathrm{C}-5, \mathrm{C}-9$ and $\mathrm{C}-15$ were restricted as $5 \beta, 9 \beta$ and $15 \beta$, respectively. Thus, the structure of $\mathbf{1}$ was determined to be as shown (Figure 1 ) and elucidated as $7 \beta$, $13 \beta$-dihydroxy-6 $\alpha$-O- $\beta$-D-glucopyranosyl-ent-kauran-16-en-19-oic acid, named as arenterpenoid A (1).

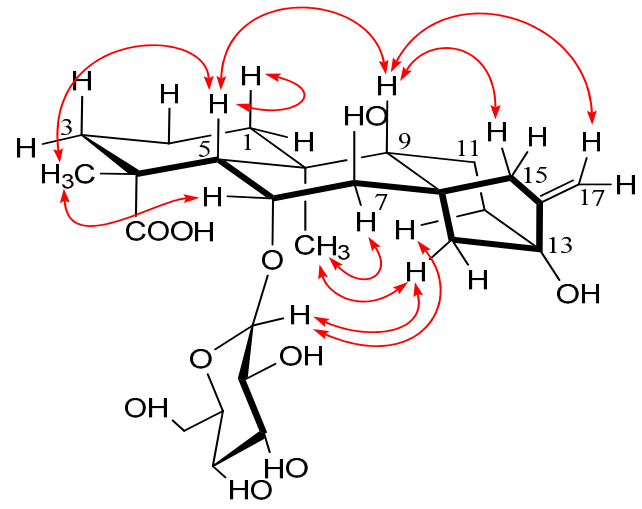

1
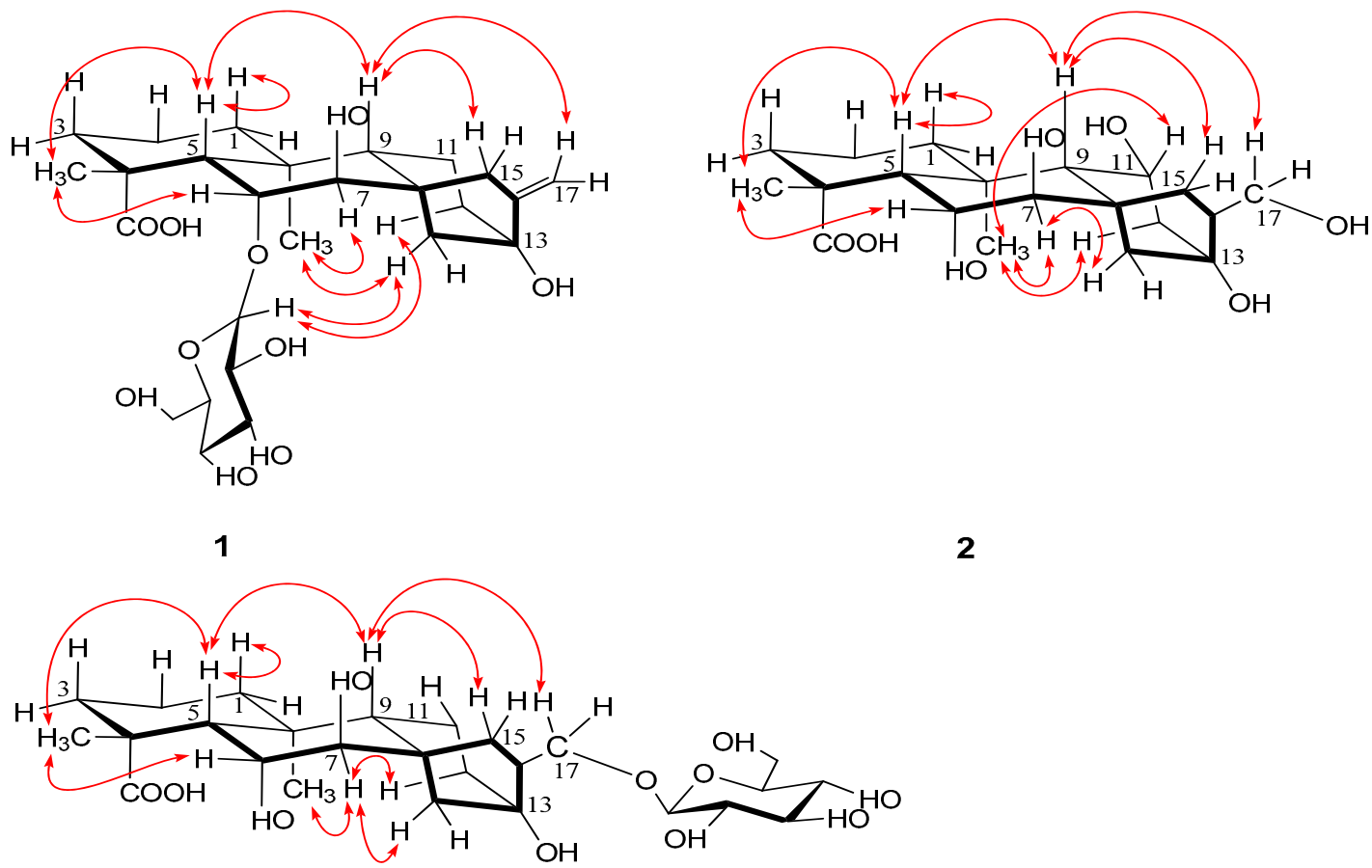

2

3

Figure 3. Key NOESY correlations of compound 1-3.

Compound 2 possessed the molecular formula of $\mathrm{C}_{20} \mathrm{H}_{32} \mathrm{O}_{7}$ according to the HR-ESI-MS at $m / z$ $385.2186[\mathrm{M}+\mathrm{H}]^{+} .{ }^{1} \mathrm{H}$ - and ${ }^{13} \mathrm{C}-\mathrm{NMR}$ spectra indicated that the structure of 2 was similar to that of $\mathbf{1}$, except for a 11-methylene group $\left(\delta_{\mathrm{H}} 1.52(\mathrm{~m}) ; \delta c 19.8\right.$ in 1), 16-olefinic proton group ( $\left.\delta \mathrm{c} 158.0 \mathrm{in} 1\right)$ and

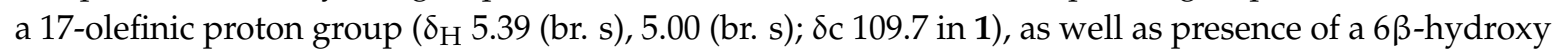
group $\left(\delta_{\mathrm{H}} 4.54(\mathrm{dd}) ; \delta c 85.2\right.$ in 2$)$, a $11 \beta$-hydroxy group $\left(\delta_{\mathrm{H}} 3.95(\mathrm{~m}) ; \delta \mathrm{c} 65.5\right.$ in 2$)$, a 16-homomethyl group $\left(\delta_{\mathrm{H}} 2.03(\mathrm{~m}), \delta \mathrm{c} 43.1\right.$ in 2$)$ and a 17-hydroxy group $\left(\delta_{\mathrm{H}} 3.75(\mathrm{~d}) ; \delta \mathrm{c} 68.1\right.$ in 2$) .{ }^{13} \mathrm{C}-\mathrm{NMR}$ and DEPT spectrum (Table 1) of 2 showed an ent-kauran-type diterpene skeleton [22]. The connectivity of these partial structures and the functional groups were investigated by analysis of HMBC of 2. As shown in Figure 2, long range correlations were observed between the following protons and carbon signals: H-18 $\left(\mathrm{CH}_{3}\right)$ and C-3, C-4, C-5, C-19 (COOH); H-20 ( $\left.\mathrm{CH}_{3}\right)$ and C-1, C-5, C-9, C-10; H-14 and C-7, C-8, C-9, C-13; H-15 and C-8, C-15; H-17 and C-13, C-15. Thus, structure 2 was confirmed as shown in Figure 2.

The relative stereochemistry of 2 was assigned by analysis of the NOESY spectrum. The ${ }^{1} \mathrm{H}-$ and ${ }^{13} \mathrm{C}-\mathrm{NMR}$ spectra showed similar data for $\mathbf{1}$ and 2 . Thus, it was determined that H-6 was in the $\beta$-orientation and that $\mathrm{H}-7$ was in the $\alpha$-orientation. The correlations of $\mathrm{H}-6 / \mathrm{H}-18$ showed that they were cofacial and were arbitrarily assigned to be $\beta$-oriented. H-5, H-9 and $\mathrm{H}-15$ were determined by their correlations with H-18. H-20 and H-11 were determined by their correlations with H-7. Thus, 
the structure of 2 was determined to be as shown (Figure 1) and elucidated as, $6 \alpha, 7 \beta, 11 \beta, 13 \beta$, 17-pentahydroxy-ent-kauran-19-oic acid, named as arenterpenoid B (2).

Table 1. ${ }^{1} \mathrm{H}$ - and ${ }^{13} \mathrm{C}-\mathrm{NMR}$ Data of $1-3\left(\mathrm{CD}_{3} \mathrm{OD}\right)$.

\begin{tabular}{|c|c|c|c|c|c|c|}
\hline \multirow{2}{*}{ NO. } & \multicolumn{2}{|l|}{1} & \multicolumn{2}{|l|}{2} & \multicolumn{2}{|l|}{3} \\
\hline & $\delta_{\mathrm{H}}(\mathrm{J}, \mathrm{Hz})$ & $\delta_{C}$ & $\delta_{\mathrm{H}}(\mathrm{J}, \mathrm{Hz})$ & $\delta_{C}$ & $\delta_{\mathrm{H}}(\mathrm{J}, \mathrm{Hz})$ & $\delta_{C}$ \\
\hline \multirow[t]{2}{*}{1} & $1.53(\mathrm{~m})$ & 38.4 & $1.88(\mathrm{~m})$ & 37.1 & $1.06(\mathrm{~m})$ & 38.4 \\
\hline & $1.04(\mathrm{~m})$ & & $1.73(\mathrm{~m})$ & & $1.55(\mathrm{~m})$ & \\
\hline 2 & $1.53(\mathrm{~m})$ & 18.4 & $1.41(\mathrm{~m})$ & 18.6 & $1.54(\mathrm{~m})$ & 18.3 \\
\hline \multirow[t]{2}{*}{3} & $2.01(\mathrm{~m})$ & 29.2 & $1.83(\mathrm{~m})$ & 24.1 & $2.00(\mathrm{~m})$ & 29.2 \\
\hline & $1.40(\mathrm{~m})$ & & $1.65(\mathrm{~m})$ & & $1.42(\mathrm{~m})$ & \\
\hline 4 & & 43.0 & & 43.2 & & 43.1 \\
\hline 5 & $1.88(\mathrm{~d}, 6.5)$ & 52.7 & $1.85(\mathrm{~d}, 7.3)$ & 51.4 & $1.82(\mathrm{~d}, 6.5)$ & 52.8 \\
\hline 6 & $4.62(\mathrm{dd}, 6.5,6.5)$ & 84.9 & $4.54(\mathrm{dd}, 7.3,7.3)$ & 85.2 & $4.56(\mathrm{dd}, 6.5,6.5)$ & 85.2 \\
\hline 7 & $4.26(\mathrm{~d}, 6.5)$ & 72.2 & $4.14(\mathrm{~d}, 7.3)$ & 72.3 & $4.23(\mathrm{~d}, 6.5)$ & 72.1 \\
\hline 8 & & 44.6 & & 48.2 & & 48.0 \\
\hline 9 & $1.17(\mathrm{dd}, 4.9,12.1)$ & 56.2 & $1.17(\mathrm{dd}, 4.7,12.1)$ & 59.7 & $1.17(\mathrm{~m})$ & 58.8 \\
\hline 10 & & 35.2 & & 37.2 & & 35.4 \\
\hline 11 & $1.52(\mathrm{~m})$ & 19.8 & $3.95(\mathrm{~m})$ & 65.5 & $1.36(\mathrm{~m})$ & 18.3 \\
\hline \multirow[t]{2}{*}{12} & $2.31(\mathrm{dd}, 7.5,13)$ & 39.2 & $1.76(\mathrm{~m})$ & 49.7 & $1.79(\mathrm{~m})$ & 24.4 \\
\hline & & & $1.37(\mathrm{~m})$ & & $1.68(\mathrm{~m})$ & \\
\hline 13 & & 85.4 & & 86.0 & & 85.4 \\
\hline \multirow[t]{2}{*}{14} & $2.05(\mathrm{~d}, 10.9)$ & 39.9 & $2.12(\mathrm{~d}, 13.0)$ & 47.5 & $2.17(\mathrm{~d}, 13.2)$ & 47.6 \\
\hline & $1.74(\mathrm{~m})$ & & $1.16(\mathrm{~d}, 13.0)$ & & $1.16(\mathrm{~d}, 13.2)$ & \\
\hline \multirow[t]{2}{*}{15} & 2.81 (br. d, 14.9) & 42.0 & $2.05(\mathrm{~m})$ & 33.5 & $2.09(\mathrm{~m})$ & 33.6 \\
\hline & $1.78(\mathrm{~m})$ & & $1.49(\mathrm{~d}, 12.6)$ & & $1.53(\mathrm{~m})$ & \\
\hline 16 & & 158.0 & $2.03(\mathrm{~m})$ & 43.1 & $2.05(\mathrm{~m})$ & 43.8 \\
\hline \multirow[t]{2}{*}{17} & 5.39 (br. s) & 109.7 & $3.75(\mathrm{~d}, 11.5)$ & 68.1 & $4.27(\mathrm{~d}, 10.4)$ & 76.2 \\
\hline & 5.00 (br. s) & & $3.58(\mathrm{~d}, 11.5)$ & & $3.46(d, 10.4)$ & \\
\hline 18 & $1.28(\mathrm{~s})$ & 25.9 & $1.34(\mathrm{~s})$ & 24.7 & $1.27(\mathrm{~s})$ & 25.8 \\
\hline 19 & & 184.8 & & 185.1 & & 185.0 \\
\hline 20 & $0.86(\mathrm{~s})$ & 20.9 & $0.98(\mathrm{~s})$ & 23.4 & $0.85(\mathrm{~s})$ & 20.9 \\
\hline $1^{\prime}$ & $4.40(\mathrm{~d}, 7.8)$ & 100.1 & & & $4.28(\mathrm{~d}, 7.7)$ & 100.1 \\
\hline $2^{\prime}$ & $3.16(\mathrm{~m})$ & 75.2 & & & $3.21(\mathrm{~m})$ & 75.2 \\
\hline $3^{\prime}$ & $3.37(\mathrm{~m})$ & 78.1 & & & $3.37(\mathrm{~m})$ & 78.1 \\
\hline $4^{\prime}$ & $3.28(\mathrm{~m})$ & 71.7 & & & $3.28(\mathrm{~m})$ & 71.7 \\
\hline $5^{\prime}$ & $3.28(\mathrm{~m})$ & 78.0 & & & $3.28(\mathrm{~m})$ & 78.0 \\
\hline \multirow[t]{2}{*}{$6^{\prime}$} & $3.83(\mathrm{dd}, 2.1,12.0)$ & 62.9 & & & $3.88(\mathrm{dd}, 2.1,12.0)$ & 62.9 \\
\hline & $3.59(\mathrm{~m})$ & & & & $3.65(\mathrm{~m})$ & \\
\hline
\end{tabular}

Compound 3 possessed the molecular formula of $\mathrm{C}_{26} \mathrm{H}_{42} \mathrm{O}_{11}$ according to the HR-ESI-MS at $m / z 531.2769[\mathrm{M}+\mathrm{H}]^{+}$. The acid hydrolysis of 2 liberated D-glucose, which was identified by HPLC analysis using an optical rotation detector. ${ }^{1} \mathrm{H}$ - and ${ }^{13} \mathrm{C}-\mathrm{NMR}$ spectra indicated that the structure of 3 was similar to that of 2, except for a $11 \beta$-hydroxy group $\left(\delta_{\mathrm{H}} 3.95 ; \delta \mathrm{c} 65.5\right.$ in 2$)$ and 17-hydroxy group $\left(\delta_{\mathrm{H}} 3.75 ; \delta \mathrm{c} 68.1\right.$ in 2$)$, as well as the presence of a 11-methylene group $\left(\delta_{\mathrm{H}} 1.36 ; \delta \mathrm{c} 18.3\right.$ in 3$)$, and 17 -( $\beta$-glucopyranosyl oxy) group $\left(\delta_{\mathrm{H}} 4.2,3.46 ; \delta \mathrm{c} 76.2\right.$ in 3$)$. The connectivity of these partial structures and the functional groups were investigated by analysis of the HMBC of 3 . As shown in Figure 2, long range correlations were observed between the following protons and carbon signals: $\mathrm{H}-18\left(\mathrm{CH}_{3}\right)$ and C-3, C-4, C-5, C-19 (COOH); H-20 ( $\left.\mathrm{CH}_{3}\right)$ and C-1, C-5, C-9, C-10; H-15 and C-7, C-8, C-9, C-16; H-7 and C-8, C-14, C-15; H-17 and C-13, C-16, C- $1^{\prime}$. Thus, the structure of 3 was confirmed as shown in Figure 2.

The relative stereochemistry of 3 was assigned by analysis of the NOESY spectrum. The ${ }^{1} \mathrm{H}-$ and ${ }^{13} \mathrm{C}-\mathrm{NMR}$ spectra showed similar data for 3 and 2 . Likewise, it was determined that $\mathrm{H}-6$ was in the $\beta$-orientation and that H-7 was in the $\alpha$-orientation. The NOESY of 3 showed the cross-peaks between H-6 and H-18, H-5, H-9; H-7 and H-20. The results showed that the stereochemistry of 3 
is similar to the stereochemistry of $\mathbf{2}$. Therefore, the structure of $\mathbf{3}$ was determined to be as shown (Figure 1) and elucidated as, $6 \alpha, 7 \beta, 13 \beta$-trihydroxy-17-O- $\beta$-D-glucopyranosyl-ent-kauran-19-oic acid, named as arenterpenoid $C(3)$. The other compounds were characterized as pseudaminic acid (4), $12 \alpha$-( $\beta$-D-glucopyranosyl)-7 $\beta$-hydroxy-kaurenolide (5), paniculoside (6), agittarioside $b(7)$, orychoside B (8) by comparing their NMR spectroscopic data with the literature values (Figures S1-S5 and Table S1).

All these compounds are reported here for the first time in Arenga genus. The kaurane type diterpene is a kind of tetracyclic diterpene with hydrogenated phenanthrene as the mother nucleus [23]. According to the structural rule of the kauri-type diterpene, the compounds 1-8 are all C-20 unoxidized kauri-type. Most of such structures isolated and artificially synthesized in plants have significant biological activities, such as antimicrobial activity and cytotoxicity [24]. This study provides an experimental and scientific basis for drug design and discovery in A. pinnata fruits.

\section{Experimental Section}

\subsection{General Experimental Procedures}

NMR spectra were measured on a Bruker AV-400 spectrometer (Bruker Company, Waltham MA, USA) with TMS as an internal standard. High-resolution ESI-MS mass spectra were carried out on an AB SCEIX Triple-TOFTM 5600 ${ }^{+}$instrument (A.B. Company, Milwaukee, WI, USA). UV spectra were recorded on a PerkinElmer Lambda UV-365 instrument (PE Company, Waltham MA, USA). IR spectra were recorded on a PerkinElmer Spectrum Two spectrometer (PE Company, Waltham MA, USA) with KBr disks. Preparative HPLC (515-2414, Waters, Milford, CT, USA) was performed on 5C18 MS-II (10 $\mu \mathrm{m}, 20 \times 250 \mathrm{~mm}$, cat. no.: 38024-01, COSMOSIL, Tokyo, Japan). $\mathrm{NH}_{2}$ column $(4.6 \times 250 \mathrm{~mm}$, cat. no.: S1119, Kasei Company, Tokyo, Japan), silica gel (200-300 mesh, Haiyang Co, Qingdao, China), Amberlite IRA-400 (OH-, Alfa Aesar, Heysham, UK) and ODS (50 $\mu \mathrm{m}$, AAG12S50, YMC Company, Kyoto, Japan) were used for column chromatography. Detectors (2424, ELS, Waters) and (2998, PDA, Waters) were used in the HPLC. Precoated silica GF 254 plates (Haiyang Company, Qingdao, China) were used for TLC analysis. All the solvents were of analytical grade (Tianjinfuyu Company Ltd., Tianjin, China).

\subsection{Plant Material}

The A. pinnata fruits were collected from Guangxi in China during September 2017, and authenticated by Prof. Weiming Wang of the Heilongjiang Research institute of Chinese Medicine. The fruitage had been deposited at the Heilongiiang Research institute of Chinese Medicine.

\subsection{Extraction and Isolation}

The A. pinnata fresh fruits $(30.0 \mathrm{~kg})$ were extracted with $70 \% \mathrm{EtOH}(200 \mathrm{~L} \times 3 \mathrm{~h} \times 3$ times). The combined extract was concentrated under vacuum yielding a residue $(3.0 \mathrm{~kg})$ which was dissolved in $\mathrm{H}_{2} \mathrm{O}(12 \mathrm{~L})$ and extracted sequentially with petroleum, chloroform, ethyl acetate and n-butanol (12 L $\times 3 \mathrm{~h} \times 5$ times). The eluate was separately concentrated in vacuo to give a petroleum syrup (109.0 g), chloroform syrup (123.0 g), ethyl acetate syrup (205.0 g), and an n-butanol syrup (380.0 g). In this study, we only separated the n-butanol layer. The n-butanol $(380.0 \mathrm{~g})$ extract was subject to column chromatography on silica gel $(4460.0 \mathrm{~g})$ and eluted with $\mathrm{CH}_{2} \mathrm{Cl}_{2} / \mathrm{MeOH}(20: 1(80.0 \mathrm{~L}), 10: 1(110.0 \mathrm{~L})$, 5:1 $(120.0 \mathrm{~L}), 3: 1(100.0 \mathrm{~L}), 2: 1(80.0 \mathrm{~L})$ and $1: 1(60.0 \mathrm{~L}), v / v)$ to afford six fractions (fractions A $(36.0 \mathrm{~g})$, B (96.7 g), C (90.2 g), D (40.1 g), E (21.2 g), F (20.1 g). The TLC and HPLC were used to observe each of the fractions, and similar fractions were combined to afford A1-A6, B1-B5, C1-C6, D1-D6, E1-E10, F1-F6. Fraction B4 (21.7 g) was eluted by Rp-18 $(600.0 \mathrm{~g})\left(\mathrm{MeOH} / \mathrm{H}_{2} \mathrm{O} 2: 8(1.4 \mathrm{~L}) \rightarrow 3: 7(2.0 \mathrm{~L}) \rightarrow 4: 6\right.$ $(2.7 \mathrm{~L}) \rightarrow 5: 5(2.0 \mathrm{~L}) \rightarrow 6: 4(2.0 \mathrm{~L}) \rightarrow 7: 3(1.4 \mathrm{~L}) \rightarrow 8: 2(1.4 \mathrm{~L}) \rightarrow 9: 1(0.8 \mathrm{~L}) \rightarrow 1: 0(1.0 \mathrm{~L}), v / v)$ to afford nine subfractions (subfractions B4-1-B4-9). Subfraction B4-6 further purified by a preparative RP-HPLC $\left(55 \% \mathrm{MeOH} / \mathrm{H}_{2} \mathrm{O}\right.$, flow rate $\left.5 \mathrm{~mL} / \mathrm{min}\right)$ to give $\mathbf{1}\left(100.12 \mathrm{mg}, \mathrm{t}_{\mathrm{R}}=23 \mathrm{~min}\right)$. Subfractions $\mathrm{B} 4-5$ were 
further purified by a preparative RP-HPLC $\left(55 \% \mathrm{MeOH} / \mathrm{H}_{2} \mathrm{O}\right.$, flow rate $\left.5 \mathrm{~mL} / \mathrm{min}\right)$ to give $2(9.52 \mathrm{mg}$, $\left.\mathrm{t}_{\mathrm{R}}=42 \mathrm{~min}\right)$. Fraction C1 (8.0 g) was eluted by Rp-18 (600.0 g) $(\mathrm{MeOH} / \mathrm{H} 2 \mathrm{O} 2: 8(1.4 \mathrm{~L}) \rightarrow 3: 7(2.0 \mathrm{~L}) \rightarrow 4: 6$ $(2.7 \mathrm{~L}) \rightarrow 5: 5(2.7 \mathrm{~L}) \rightarrow 6: 4(2.0 \mathrm{~L}) \rightarrow 7: 3(1.4 \mathrm{~L}) \rightarrow 8: 2(1.4 \mathrm{~L}) \rightarrow 9: 1(0.8 \mathrm{~L}) \rightarrow 1: 0(1.0 \mathrm{~L}), v / v)$ to afford nine subfractions (subfractions $\mathrm{C} 1-1-\mathrm{C} 1-9)$. Subfractions $\mathrm{C} 1-3$ were further purified by a preparative RP-HPLC $\left(20 \% \mathrm{MeOH} / \mathrm{H}_{2} \mathrm{O}\right.$, flow rate $\left.5 \mathrm{~mL} / \mathrm{min}\right)$ to give $4\left(11.89 \mathrm{mg}, \mathrm{t}_{\mathrm{R}}=30 \mathrm{~min}\right)$. Subfraction C1-5 were further purified by a preparative RP-HPLC $\left(45 \% \mathrm{MeOH} / \mathrm{H}_{2} \mathrm{O}\right.$, flow rate $\left.5 \mathrm{~mL} / \mathrm{min}\right)$ to give $5\left(8.50 \mathrm{mg}, \mathrm{t}_{\mathrm{R}}=25 \mathrm{~min}\right)$. Fraction D3 $(18.0 \mathrm{~g})$ was eluted by Rp-18 $(600.0 \mathrm{~g})\left(\mathrm{MeOH} / \mathrm{H}_{2} \mathrm{O} 2: 8\right.$ $(1.4 \mathrm{~L}) \rightarrow 3: 7(2.0 \mathrm{~L}) \rightarrow 4: 6(2.7 \mathrm{~L}) \rightarrow 5: 5(2.7 \mathrm{~L}) \rightarrow 6: 4(2.7 \mathrm{~L}) \rightarrow 7: 3(1.4 \mathrm{~L}) \rightarrow 8: 2(1.4 \mathrm{~L}) \rightarrow 9: 1(0.8 \mathrm{~L}) \rightarrow 1: 0$ $(1.0 \mathrm{~L}), v / v)$ to afford nine subfractions (subfractions D3-1-D3-9). Subfractions D3-6 were further purified by a preparative RP-HPLC $\left(40 \% \mathrm{MeOH} / \mathrm{H}_{2} \mathrm{O}\right.$, flow rate $\left.5 \mathrm{~mL} / \mathrm{min}\right)$ to give $3\left(10.61 \mathrm{mg}\right.$, $\mathrm{t}_{\mathrm{R}}$ $=32 \mathrm{~min})$. Subfraction D3-6 were further purified by a preparative RP-HPLC $\left(45 \% \mathrm{MeOH} / \mathrm{H}_{2} \mathrm{O}\right.$, flow rate $5 \mathrm{~mL} / \mathrm{min})$ to give $8\left(4.51 \mathrm{mg}, \mathrm{t}_{\mathrm{R}}=41 \mathrm{~min}\right)$. Subfractions $\mathrm{D} 3-4$ were further purified by a preparative $\mathrm{RP}-\mathrm{HPLC}\left(60 \% \mathrm{MeOH} / \mathrm{H}_{2} \mathrm{O}\right.$, flow rate $\left.5 \mathrm{~mL} / \mathrm{min}\right)$ to give $6\left(70.67 \mathrm{mg}, \mathrm{t}_{\mathrm{R}}=29 \mathrm{~min}\right)$. Subfractions D3-5 were further purified by a preparative RP-HPLC $\left(60 \% \mathrm{MeOH} / \mathrm{H}_{2} \mathrm{O}\right.$, flow rate $5 \mathrm{~mL} / \mathrm{min}$ ) to give $7\left(4.32 \mathrm{mg}, \mathrm{t}_{\mathrm{R}}=37 \mathrm{~min}\right)$.

Arenterpenoids A (1). Yellow amorphous powder. Gave $[\alpha]_{\mathrm{D}}^{25}+10.0(\mathrm{c}=1.76, \mathrm{MeOH}) ; \mathrm{IR}(\mathrm{KBr})$ 3436, 2946, 2835, 1719, 1635, 1467, 1231, and $1069 \mathrm{~cm}^{-1} ;{ }^{1} \mathrm{H}-$ and ${ }^{13} \mathrm{C}-\mathrm{NMR}(\mathrm{MeOH}, 400,100 \mathrm{MHz})$ data, see Table 1; HR-ESI-MS $m / z$ 513.2651 $[\mathrm{M}+\mathrm{H}]^{+}$(calc. for $\mathrm{C}_{26} \mathrm{H}_{40} \mathrm{O}_{10}, 513.2655$ ) (Figures 1 and 2).

Arenterpenoids B (2). Yellow amorphous powder. Gave $[\alpha]_{\mathrm{D}}^{25}-31.6(\mathrm{c}=0.66, \mathrm{MeOH})$; IR $(\mathrm{KBr})$ 3381, 2931, 1730, 1664, 1451, 1229, and $1039 \mathrm{~cm}^{-1} ;{ }^{1} \mathrm{H}$ - and ${ }^{13} \mathrm{C}-\mathrm{NMR}(\mathrm{MeOH}, 400,100 \mathrm{MHz}$ ) data, see Table 1; HR-ESI-MS $m / z 385.2186[\mathrm{M}+\mathrm{H}]^{+}$(calc. for $\mathrm{C}_{20} \mathrm{H}_{32} \mathrm{O}_{7}$, 385.2182) (Figures 1 and 2).

Arenterpenoids C (3). White amorphous powder. Gave $[\alpha]_{\mathrm{D}}^{25}-21.6(\mathrm{c}=0.48, \mathrm{MeOH}) ; \mathrm{IR}(\mathrm{KBr})$ $3358,2949,1716,1662,1460,1225$, and $1070 \mathrm{~cm}^{-1} ;{ }^{1} \mathrm{H}$ - and ${ }^{13} \mathrm{C}-\mathrm{NMR}(\mathrm{MeOH}, 400,100 \mathrm{MHz})$ data, see Table 1; HR-ESI-MS $m / z 531.2769[\mathrm{M}+\mathrm{H}]^{+}$(calcd. for $\mathrm{C}_{26} \mathrm{H}_{42} \mathrm{O}_{11}, 531.2761$ ) (Figures 1 and 2).

\subsection{Acid Hydrolysis and HPLC Analysis}

The isolated compounds $(\mathbf{1}, \mathbf{3})(2.0 \mathrm{mg})$ were in $1.0 \mathrm{~mL} \mathrm{HCl}$ and were each heated under reflux for $3 \mathrm{~h}$. After cooling, the two mixtures were separately filtered with Amberlite IRA-400 to give a solution. Assigned with AcOEt to get two layers. The aqueous layer was evaporated to dryness under vacuum, and then subjected to HPLC analysis using an $\mathrm{NH}_{2}$ column and an optical-rotation detector. D-glucose was confirmed by comparison of the $t_{R}$ with that of an authentic sample (mobile phase: $\mathrm{MeCN} / \mathrm{H}_{2} \mathrm{O}$ 85: $15(v / v)$; flow rate: $0.8 \mathrm{~mL} / \mathrm{min} ; \mathrm{t}_{\mathrm{R}}=12.8 \mathrm{~min}$ (D-glucose, positive optical rotation))

\section{Conclusions}

As a traditional Chinese medicine, $A$. pinnata fruits were mainly used to treat rheumatism and bone pain. This study obtained eight diterpene compounds from $A$. pinnata fruits, including three new diterpenes and five known ones. This also reveals some structural characteristics of the chemical constituents in the A. pinnata fruit, which provides some clues for further clarifying the composition of the components and correlations of the relative plant species. In this study we have made this contribution to discover active ingredients and leading compounds and additionally provided an experimental and scientific basis of drug design and drug discovery of the A. pinnata fruits.

Supplementary Materials: The following are available online: Figures S1-S5 and Table S1: The ${ }^{13}$ C-NMR data of Compounds 4-8.

Author Contributions: W.-M.W. and L.-Q.H. designed the experiments; J.-F.L. and C.W. performed the experiments; J.-F.L. wrote the paper. W.-M.W., F.-J.L. and J.-H.H. modified the paper; All authors read and approved the manuscript.

Funding: This work was financed by key projects at the central government level: The ability establishment of sustainable use for valuable Chinese medicine resources (2060302) and Supported by China Agriculture Research System (CARS-21).

Conflicts of Interest: The authors declare no conflict of interest. 


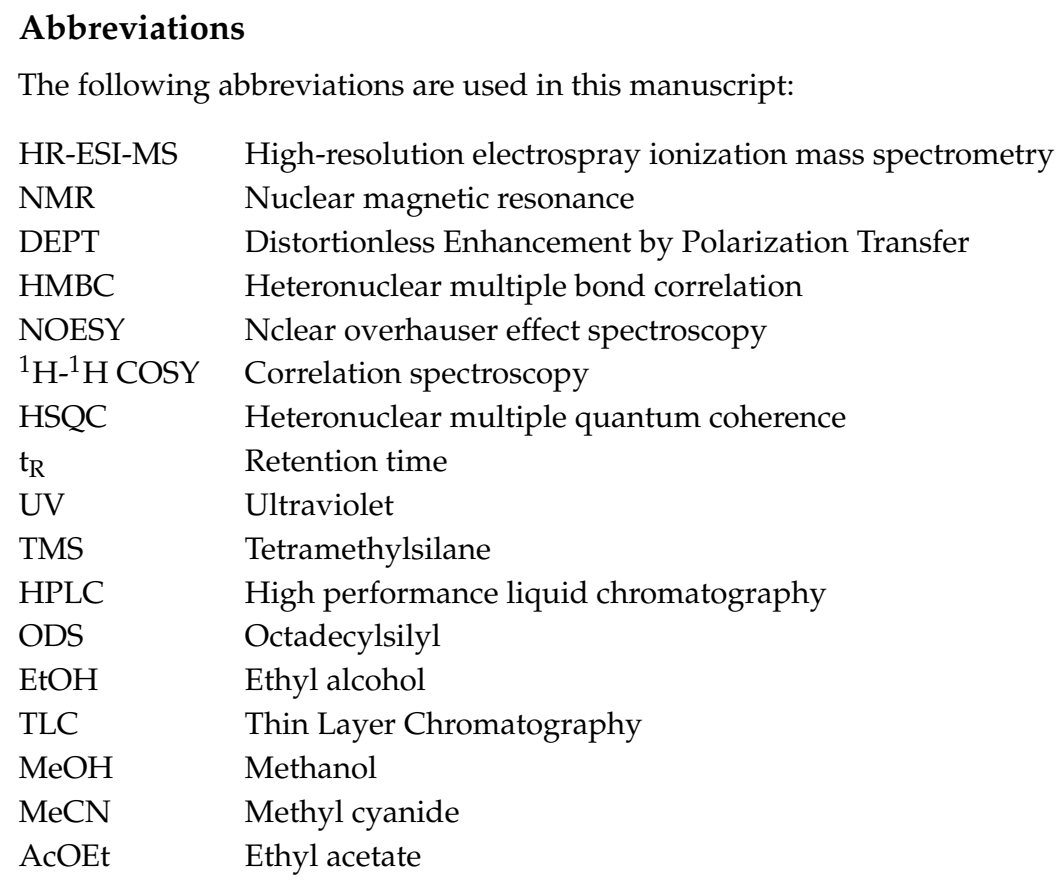

\section{References}

1. Editorial Board of Chinese Academy of Sciences. Flora of China; Science and Technology Publishing House: Beijing, China, 1991; Volume 3, p. 108.

2. Lu, D.X.; Shang, Z.J. Kai Bao Ben Cao; Anhui Science and Technology Publishing House: Anhui, China, 1998.

3. Ni, Z.M.; Zheng, J.S.; Qi, X.Y. Ben Cao Hui Yan; Shanghai Science and Technology Publishing House: Shanghai, China, 2005.

4. Su, S. Ben Cao Tu Jing; Anhui Science and Technology Publishing House: Anhui, China, 1994.

5. Li, S.Z. Compendium of Materia Medica; People's Health Publishing House: Beijing, China, 2005; p. 31.

6. Lin, Q.; Fu, L.G. Higher Plants of China; Qingdao Publishing House: Qingdao, China, 2009.

7. Mu, X.N.; Yang, W.Q.; Wang, W.J. Chemical constituents from the fruits of Areca catechu. Chin. Med. Mat. 2014, 35, 56-60.

8. Chen, Q.M.; Deng, Z.; Guo, F.W. Constituent Analysis of Volatile Organic Compounds in Three Palmae. J. Anhui Agric. 2017, 45, 152-154.

9. Zeng, Q. Chemical Constituents from the Fruits of Areca catechu. Master's Thesis, Central South University of Forestry and Technology, Changsha, China, 2013.

10. Gui, Y.M. Studies on Diterpenes Constituents and Anti Tumor Activity of Rabdosia excisa. Ph.D. Thesis, Jilin University, Changchun, China, 2013.

11. Guan, Y.G.; Hu, W.Z.; Shi, Y.S. Research Progress in Terpene Constituents and Biological Activities of Pteris. Chin. J. Exp. Tradit. Med. Form. 2018, 24, 219-227.

12. Zhao, X.Y.; Cai, X.; Hu, Z.H. Research progress on biology, chemical constituents in Euphorbia kansui, and their pharmacological effects. Chin. Tradit. Herbal. Drugs 2014, 45, 3029-3033.

13. Gong, X.L.; Chen, Z.H.; Liang, N.C. Isolation and identification of glycoside of compound 5F from Pterissemi pinnata L. and their antitumor activity. Chin. Med. Mat. 2010, 32, 257-260.

14. Toshiyuki, M.; Kentarou, K.; Hisashi, M. Medicinal foodstuffs. XXII. Structures of oleanane-type triterpene oligoglycosides, pisumsaponins I and II, and kaurane-type diterpene oligoglycosides, pisumosides A and B, from green peas, the immature seeds of Pisum sativum L. Chem. Pharm. Bull. 2001, 49, 73-77.

15. Takashi, K.; Hiromi, A.; Ken-Ichiro, M. Two new ent-kaurane-type diterpene glycosides from zucchini (Cucurbita pepo L.) seeds. Fitoterapia 2015, 107, 69-76.

16. Cai, X.F.; Shen, G.; Dat, N.T. Inhibitory Effect of Kaurane Type diterpenes from Acanthopanax koreanum on TNF- $\alpha$ Secretion from Trypsin-Stimulated HMC-1 Cells. Arch. Pharm. Res. 2003, 26, 731-734. [CrossRef] [PubMed] 
17. Yoshikawa, M.; Yoshizumi, S.; Murakami, T. Medicinal foodstuffs. II. On the bioactive constituents of the tuber of Sagittaria trifolia L. (Kuwai, Alismataceae): Absolute stereostructures of trifoliones A, B, C, and D, sagittariosides a and b, and arabinothalictoside. Chem. Pharm. Bull. 1996, 44, 492-499. [CrossRef] [PubMed]

18. Ohkoshi, E.; Kamo, S.; Makino, M. Ent-kaurenoic acids from Mikania hirsutissima (compositae). Phytochemistry 2004, 65, 885-890. [CrossRef] [PubMed]

19. Zhang, G.; Cui, H.; Liu, S.; Dong, J. A new triterpenoid saponin and a diterpene glucoside from the seeds of Orychophragmus violaceus. Nat. Prod. Res. 2018, 46, 1-7. [CrossRef] [PubMed]

20. Murakami, T.; Kohno, K.; Kishi, A.; Matsuda, H. Medicinal foodstuffs. XIX. Absolute stereostructures of canavalioside, a new Ent-kaurane-type diterpene glycoside, and gladiatosides A1, A2, A3, B1, B2, B3, C1, and C2, new acylated flavonol glycosides, from sword bean, the seeds of Canavalia gladiata. Chem. Pharm. Bull. 2000, 48, 1673-1680. [CrossRef] [PubMed]

21. Kim, K.H.; Choi, S.U.; Lee, K.R. Diterpene glycosides from the seeds of pharbitis nil. J. Nat. Prod. 2009, 72, 1121-1127. [CrossRef] [PubMed]

22. Li, R.J.; Wang, S.; Li, G.; Zhou, J.C. Four new Kaurane diterpenoids from the Chinese liverwort Jungermannia comata Nees. Chem. Biodivers. 2016, 13, 1685-1690. [CrossRef] [PubMed]

23. Zhang, D.Y.; Li, Z.Y.; Shi, L.Y. Advances in Research on Cytotoxinic Activity of ent-Kaurance Diterpenoids. Chin. J. Ore Chem. 2008, 1911-1917.

24. Du, M.J.; Lei, X.G. Advanced in the Synthesis of Kaurane Diterpenoids. Chin. J. Ore Chem. 2015, $2447-2464$.

Sample Availability: Samples of the compounds are available from the authors.

(C) 2018 by the authors. Licensee MDPI, Basel, Switzerland. This article is an open access article distributed under the terms and conditions of the Creative Commons Attribution (CC BY) license (http://creativecommons.org/licenses/by/4.0/). 